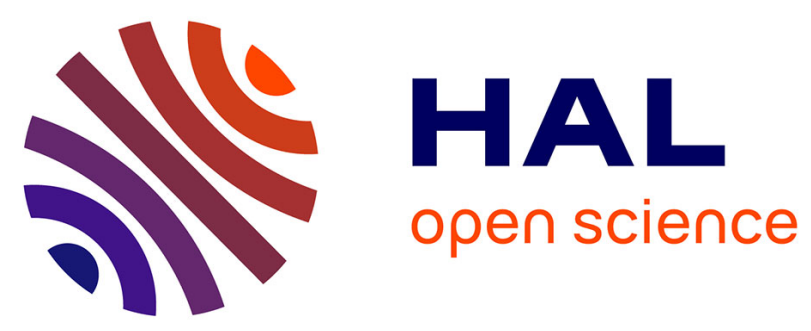

\title{
Multidisciplinary approaches for the study of sediment discharges to the Mediterranean Sea to mitigate the impact of climate and anthropogenic activities on coastal environments
}

\author{
Oula Amrouni, Yu Fisjak, Saadi Abdeljaouad, Hakim Abichou, Abdallah \\ Hattour, Nejmeddine Akrout, Chrystelle Bancon-Montigny, Thouraya \\ Benmoussa, Kerim Ben Mustapha, Lassâad Chouba, et al.
}

\section{- To cite this version:}

Oula Amrouni, Yu Fisjak, Saadi Abdeljaouad, Hakim Abichou, Abdallah Hattour, et al.. Multidisciplinary approaches for the study of sediment discharges to the Mediterranean Sea to mitigate the impact of climate and anthropogenic activities on coastal environments. 1st Springer Conference of the Arabian Journal of Geosciences (CAJG-1), Tunisia 2018, Nov 2018, Hammamet, Tunisia. pp.353-358. hal-02404493

\section{HAL Id: hal-02404493 \\ https://hal.umontpellier.fr/hal-02404493}

Submitted on 11 Dec 2019

HAL is a multi-disciplinary open access archive for the deposit and dissemination of scientific research documents, whether they are published or not. The documents may come from teaching and research institutions in France or abroad, or from public or private research centers.
L'archive ouverte pluridisciplinaire HAL, est destinée au dépôt et à la diffusion de documents scientifiques de niveau recherche, publiés ou non, émanant des établissements d'enseignement et de recherche français ou étrangers, des laboratoires publics ou privés. 


\title{
Multidisciplinary approaches for the study of sediment discharges to the Mediterranean Sea to mitigate the impact of climate and anthropogenic activities on coastal environments
}

Oula Amrouni ${ }^{1}$, Gil Mahé ${ }^{2}$, Saâdi Abdeljaouad ${ }^{3}$, Hakim Abichou ${ }^{4}$, Abdallah Hattour ${ }^{1}$, Nejmeddine Akrout ${ }^{3}$, Chrystelle Bancon-Montigny ${ }^{5}$, Thouraya Benmoussa ${ }^{3}$, Kerim Ben Mustapha ${ }^{1}$, Lassâad Chouba ${ }^{1}$, Domenico Chiarella ${ }^{6}$, Michel Condomines ${ }^{7}$, Laurent Dezileau ${ }^{7}$, Claudine Dieulin ${ }^{2}$, Nadia Gaâloul ${ }^{3}$, Ahmed Ghadoum ${ }^{8}$, Abderraouf Hzami $^{1}$, Nabil Khelifi ${ }^{9}$, Samia Khsiba ${ }^{1}$, Fatma Kotti ${ }^{2}$, Mounir Medhioub ${ }^{10}$, Hechmi Missaoui ${ }^{1}$, François Sabatier ${ }^{11}$, Alberto Sánchez ${ }^{12}$, Alessio Satta ${ }^{13}$, Abdelaziz Sebei ${ }^{3}$ and Wième Ouertani ${ }^{1}$

${ }^{1}$ National Institute of Marine Science and Technologies, 2025 Salammbô, Tunisia

${ }^{2}$ UMR HydroSciences Montpellier/IRD, 34090 Montpellier, France

${ }^{3}$ Faculty of Sciences, Campus Universitaire 2092, Tunis, Tunisia

${ }^{4}$ University of Tunis, Faculty of Human and Social Sciences of Tunis, Tunisia

${ }^{5}$ University of Monpellier, 34090 Monpellier, France

${ }^{6}$ University of London, Department of Earth Sciences, Royal Holloway, TW20 0EX Egham,

United Kingdom

${ }^{7}$ University of Montpellier II, HDR-Géosciences, France

${ }^{8}$ National Institute of Cultural Heritage, Department of Underwater Archaeology,Tunisia

${ }^{9}$ GEOMAR Helmholtz Center for Ocean Research Kiel, 24148 Kiel, Germany

${ }^{10}$ Sfax University, 3029 Sfax, Tunisia

${ }^{11}$ Aix-Marseille University - SCHUMAN - 13628, Aix-en-Provence, France

${ }^{12}$ Centro Interdisciplinario de Ciencias Marinas, La Paz, Baja California Sur, México

${ }^{13}$ University of Cagliari, DICAAR, via Marengo 2, 09123 Cagliari, Italy

Email: oula.amrounieinstm.rnrt.tn

\begin{abstract}
The present work is based on The RYSCMED project supported by PHC-UTIQUE 20162018 (16G 1005-34854QC). The RYSCMED is an interdisciplinary project which gathers different disciplines (e.g. sedimentology, hydrology, geochemistry, ecology, paleontology, biochemistry, archeology) to quantify the sediment flow of the land-sea. This research aims at identifying coastal sediment dynamics (via the sand supply sources; i.e. Medjerda River) and hydrodynamic parameters to understand the local environmental problems in an urbanized coastal framework. The outcome is expected to produce original and new findings about the link between dams, river hydrology and sediment origin to the sea, with the impact of climate and anthropogenic activities on the coastal geomorphology and ecosystem sensitivity. The main scientific outcome will be addressed
\end{abstract}


to the socio-economic actors to implement necessary solutions for remediating the Mediterranean coastal vulnerability.

Keywords: RYSCMED, Mediterranean, Medjerda River, Sediment, Coast, Sensitivity.

\section{Introduction}

The coastal areas of the Mediterranean Sea are densely inhabited and produce a valuable part of the national incomes of many countries. However, land-sea areas have suffered since the last 100 years from increased salinity, changes in geomorphology, coastline regression, coastal biodiversity reduction and increased pollution of ecosystems mostly driven by the high number of dams which reduce water and sediment flows to the sea by storing a great part of them inland. This situation is worsened by both a sustained rainfall reduction and the sea level rise due to the worldwide temperature increase. Indeed, Mediterranean areas are among the most vulnerable environments in the world due to the potential impact of climate changes [1] [2]. In this scenario, North Africa and the Middle East are most vulnerable areas [3] [4] in the face of this global problem, which urgently need a protection of their coastal landscapes.

Many initiatives have been developed in recent years to improve the knowledge on this rapidly changing overpopulated environment, and to enhance international cooperation around the Mediterranean. However, only few programs deal with the full continuum from the river basins to the coastline, and still less involve many countries from the South and East Mediterranean regions.

Hence, a multidisciplinary approaches for the study of sediment discharges to the Mediterranean Sea to mitigate the impact of climate and anthropogenic activities on coastal environments should contribute to a better understanding of the coastal areas.

The RYSCMED project has been implemented in the pre-estuarine and coastal field of the most driven river, i.e. the Medjerda in the bay of the Gulf of Tunis (Western Mediterranean, Tunisia) (Fig. 1). Actually, the low Medjerda Delta which is the main agricultural region in Tunisia and hosting industrial and fishing activities, is perceived as the highly vulnerable area to sea level rise scenario. The main tributary system of the Medjerda River discharges up to $30 \mathrm{~g}^{-1} \mathrm{l}^{-1}$ of sediment load during floods, for an annual total of 20,400 tons, of which $10 \%$ is composed of sand [5]. However, the sedimentary contributions to the coastal zone from the Medjerda River is still unknown. It is also the aim of the RYSCMED project to provide the quantitative amount of sediment yield from the Medjerda River to the sea via the coastal zone during the last 50 to 100 years. 


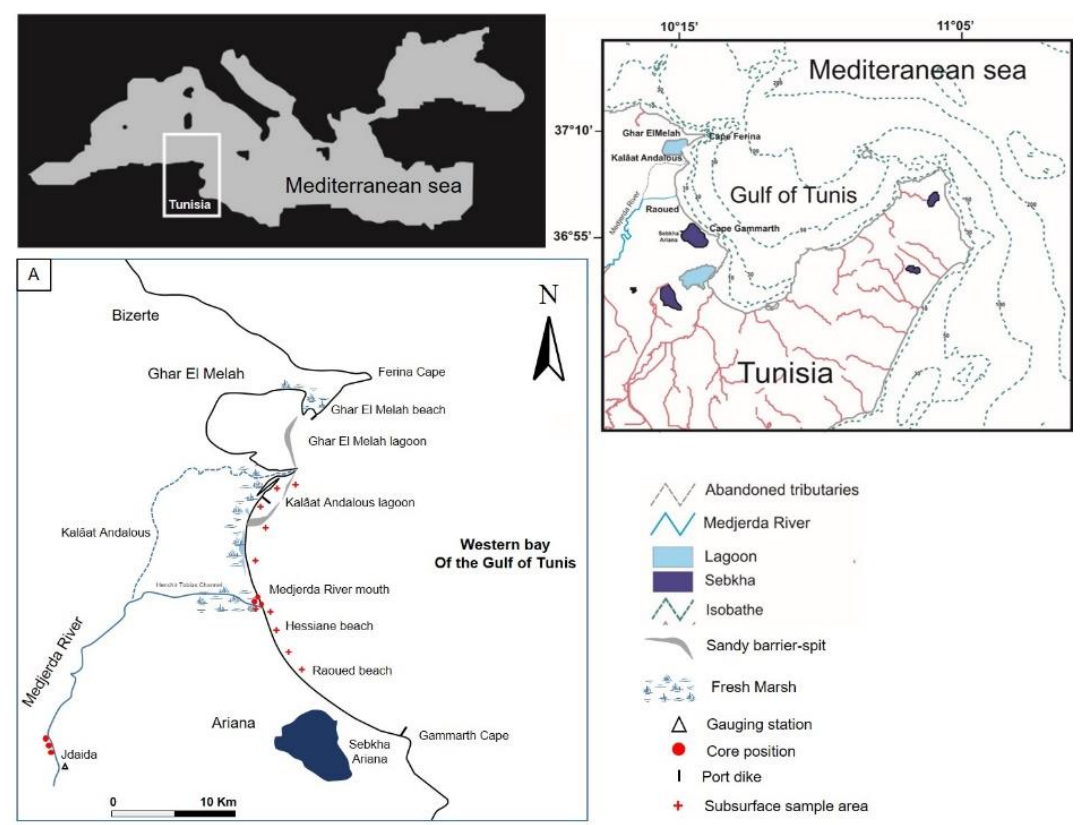

Fig. 1. The location map of the study field area of the depositional deltaic system of Medjerda River, western bay of the Gulf of Tunis (Tunisia, Mediterranean). A/ Sampling position of the core and coastal subsurface sediment reconstruction.

\section{Methods}

We propose to analyze the sediment inlet fluctuation in regard of events recorded on the inland basins: dam constructions, changes in agricultural practices and in population, and to create a sediment transfer model to the sea.

Data used are based on sediment discharges from large rivers and sediment subsurface samples and three cores in the pre-estuarine zone, downstream of the last dams and far enough three cores from the coast to avoid marine influence. In order to assess the impact of the reduction of sediment transport from the upper basins to the coastal area since the past 50-100 years (Fig. 1 A).

The River mouth nearshore, lagoon and dredged sediment were subject to sedimentological, mineralogical, geochemical and floristic analyses (campaign carried out from 2016 to 2018). Sedimentological multi approaches were based on the identification of different Sedimentary Types (ST). Accordingly, using grain size indexes (i.e., Mz, SKI and $\mathrm{Ku}$ ), Sediment Trend Analysis (STA) modeling tools were applied to define the seasonal sediment transport pathways throughout the nearshore of the Medjerda Delta. Both sediment cores were subjected to multiproxy approaches (major and trace elements and dating radiometric ${ }^{210} \mathrm{~Pb}$ and ${ }^{137} \mathrm{Cs}$ ). Surface sediment of the Medjerda River and nearshore sediment undertook geochemical study.

The evolution of the coastline of Medjerda was also estimated by satellite images carried out from SPOT1, SPOT4 and Sentinel A2 imageries (from 1936 to 2016 surveys) completed by the aerial and topographic surveys (missions: 1900, 1936, 1948, 1952, 1974, 1984, 1988, 1999 and 2016). The lagoon system of Kalâat Andalous (and 
the fishing harbor inside) was subject to ecosystemic study. We also used Fauna and flora as biologic tools to characterize physical and chemical parameters of coastal and paralic environments. The investigations were based on the study of the sedimentological facies, a floristic (Environmental Quality Ratio of macrophytes, EXCLAME index), faunistic identification and geochemical analysis ( $\mathrm{As}, \mathrm{Cd}, \mathrm{Cr}, \mathrm{Cu}, \mathrm{Ni}, \mathrm{Pb}, \mathrm{Zn}$ ).

\section{Results}

\subsection{Hydroclimatic and sedimentological evolution}

The result of the lower valley and the coastal area cores' analysis show a succession of sedimentary layers that likely correspond to different flood deposits that succeeded on this site. The dating with $\mathrm{Pb}$ and $\mathrm{Cs}$ of the cores shows that the selected area is an important deposition area. The thickest layers of sedimentary deposits were related to the exceptional events. They are mainly concentrated on the lower part of the core and are predominantly composed of sands. Since the construction of the Sidi Salem dam in 1981, all cores presented mostly a succession of small layers of fine material (silt or clay) without any sand deposits in the downstream river bed. A strong decrease in the accumulation rate of sediment was observed based on the length of the flood units and the number of years between flood events. A lower sedimentation rate (about $2.3 \mathrm{~cm} \mathrm{y}^{-}$

${ }^{1}$ ) is observed between 1982 and 2015, while it was much more important between 1963 and 1981 (about $4.75 \mathrm{~cm} \mathrm{y}^{-1}$ ), and around $10 \mathrm{~cm}^{-1} \mathrm{y}^{-1}$ between 1950 and 1962 (Fig. $2 \mathrm{~A}$ ).

Sedimentological results show a fluvial dominance marked by silt and clay deposits rich in terrigenous chemical elements since the 1950. Seasonal nearshore sediment dynamics show that grain size distribution (GSD) and Sediment Trend Analysis (STA) model pathways are determined by cross-shore geomorphology, location of the sediment-cell, seasonal incident wave and local terrestrial supply.

The geochemical signature shows a highly concentration of $\mathrm{Rb}, \mathrm{Ti}, \mathrm{Zn}$ and $\mathrm{Pb}$. Sediment deposit facies associated to the geochemical component and the 137Cs / $210 \mathrm{Pbex}$ radiometric dating of recent alluvial deposits confirm the shoreline retreat due to terrestrial sediment reduction (Fig. 2 B).

\subsection{Temporal evolution of the shoreline}

The temporal shoreline evolution is established according to the aerial surveys from 1900 to 2016. Although the general trends of the shoreline reveal an increased rate, the mesoscale qualitative monitoring displays a nonlinear shoreline and plain flood evolution. Three periods can be individualized: 1- The natural beach progression between 1900 to 1952,2 - The shoreline progression at the mouth of the new artificial channel, from 1952 to $1981\left(+13 \mathrm{~m} \pm 0.15 \mathrm{~m} \mathrm{y}^{-1}\right), 3$ - The shoreline retreat rate after the manmade construction comprised between 1981 and $2016\left(-20 \mathrm{~m} \pm 0.15 \mathrm{~m} \mathrm{y}^{-1}\right)$ The progradation and retrogradation of the Medjerda Delta during the $\mathrm{XX}^{\text {th }}$ century is strongly influenced by an anthropogenic factor (Fig. 2 C). 

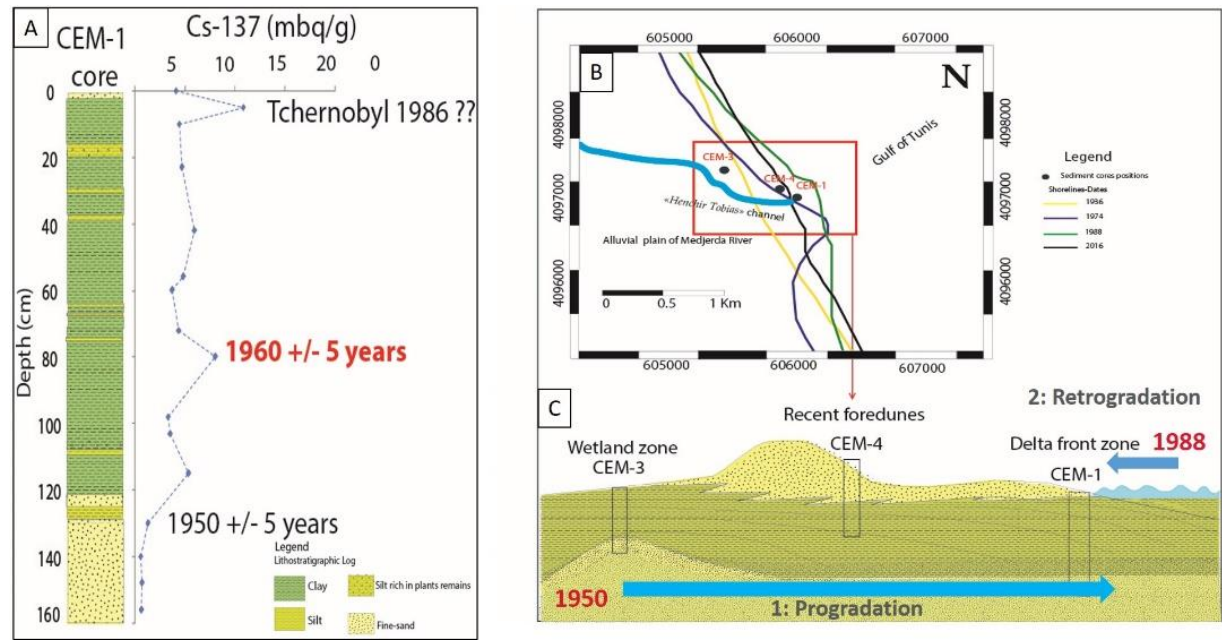

Fig. 2. A/ The downcore grain size distribution of the CEM-1 carried out on the delta front and the geochronology using ${ }^{137} \mathrm{Cs}$ activity-depth profiles. B/ The shoreline evolution analysis at the mouth of the new Medjerda River during the 1936-2016 period. C/ The diagram synthesis of morphological changes involving the development and the retrogradation of the new delta of Medjerda River during the $\mathrm{XX}^{\text {th }}$ century

\subsection{Ecological study of the wetland system}

Spatial Kalâat Andalous sediment distribution revealed that the central lagoon area is dominated by fine sand and silty sediments. Medium sand is located mainly on the north and at the south-eastern part of the lagoon. Floristic study revealed the existence of 12 species among which five reference species whose percentage is equal to $26 \%$. Reference species are Cymodocea nodosa Zostera nolti (marine phanerogams), Cystoseira barbata, Cystoseira compressa, Dictyota dichotoma (macrophytes; brown algae). This low percentage may reveal an environment quality loss and an eutrophication of the lagoon water. The latter is proved by the EXCLAME index which is equal to 0.24 indicating that the lagoon water is in a poor state. The study of microfauna and specially foraminifera has permitted to distinguish several associations related to hydrodynamic context. Some are of coastal marine affinity, others are more tolerant to stress conditions. The richness of reworked species in some samples of the lagoon denotes a strong continental impact in this humid area.

Dredged sediment of Kalaât Andalous lagoon are dominated by silts and clays, dark black in colour and relatively enriched in organic matter (with a TOC value of $1.30 \%$ ) and sulphur compounds. However, the sediments are moderately contaminated by inorganic and organic pollutants except for $\mathrm{Cd}$ which is present in relatively highly amounts $(2.85 \mathrm{ppm})$ over the standard amounts generally found in the sediment. 


\subsection{Geochemical characterization of the Delta-coast sediment yield}

The trace metals $(\mathrm{Zn}, \mathrm{Cd}, \mathrm{Cu}, \mathrm{Cr}$ and $\mathrm{Ni}$ ) analysed in subsurface sediments along the Medjerda River tributaries and along the coast are relatively high. Lead contents vary from 12 to $46 \mathrm{ppm}$. The zinc concentrations vary from 2 to $71 \mathrm{ppm}$, while cadmium concentrations vary from 0.56 to $4 \mathrm{ppm}$ (mean of $1.2 \mathrm{ppm}$ ). Chromium contents are between 46 and $178 \mathrm{ppm}$ (mean of $98 \mathrm{ppm}$ ). Copper contents vary from 27 to $67 \mathrm{ppm}$, while nickel concentrations vary from 14 to $51 \mathrm{ppm}$ (mean of $30 \mathrm{ppm}$ ). The Kalâat Andalous lagoon-habour sediment reveals a variable concentration of the MTE component ( $\mathrm{Al}, \mathrm{Fe}, \mathrm{Zn}, \mathrm{Ni}, \mathrm{Co}, \mathrm{Cu}$ et $\mathrm{Pb}, \mathrm{As}$ ) which respectively varies from 0,5 to $5,5 \%$; 0,8 to $2,5 \% ; 29$ to $158 \mathrm{ppm} ; 7$ to $29 \mathrm{ppm} ; 2$ to $9 \mathrm{ppm} ; 3$ to $31 \mathrm{ppm}, 7$ to $70 \mathrm{ppm}$ and 4 to $15 \mathrm{ppm}$.

\section{Discussion}

The RYSCMED project outcomes confirm a variable sensitivity of the deltaic transition area of the sea level rise. Morphosedimentary quantitative distribution reveals a change in the fluvial deposits facies feeding the deltaic plain with a decreasing grade and shortage of sedimentary inputs towards the sea [11]. About 10 dams have been created on the Medjerda basin, among which the largest one, Sidi Salem, with more than 1 billion $\mathrm{m}^{3}$ not far from the sea. These have a major impact on the hydrosedimentary regime downstream and undergone significant changes in morphology of the lower depositional deltaic valley and the coastal area (i.e., reduction in average rates and in volumes of solid transport, altered pattern of seasonal flows) [6].

Sedimentological studies indicate that the western bay of the Gulf of Tunis is characterized by two sediments facies: (i) mud coming from the discontinuous supplies of rivers; and (ii) sandy sediments originating from the continuous reworking of erosion of the cliffs and coastal drift throughout beach during storm events.

The dominance of clay deposits over sandy facies on the beaches results from the impact of the dam construction. Only the finer grain size fractions can feed the coast. The actual sediment balance of the Gulf of Tunis coast shows a shoreline retreat under the coarser sediment deficit blocked by upstream dam construction [7]. Archaeological surveys and remains around the site of the ancient paleo bay of Utica, the eldest sister of Carthage, confirm a rapid change and shift in the shoreline [8]

That initiates a regressive sequence of deltaic deposits over spatial and temporal variability in facies and proocess in reponse to fluvial and marine controls [9].

The textural facies of coastal system sandy components (river mouths, sandy spits, submarine sandbars) are modified towards very fine to silty sediments, becoming contaminant traps. Fluvial inputs, reduced in volume and size, work as a pollutant vector (trace elements) to adjacent beaches through coastal currents. The contaminant burden to protected areas (lagoon, bays) is related to the anthropogenic and natural component inputs. The heavy metals present in river-coast sediment have two origins: a natural source "natural background" and an anthropogenic origin. The high levels detected are mainly related to human activities (i.e., mining activities) [10]. The study of wetland 
ecosystems associated to estuary areas via biotops and biocenosis showed the high degree of coastal ecosystem sensitivity to human activities.

\section{Conclusions}

The reduction in sediment discharge to the littoral caused by the dam is the principal cause of the negative sediment budget leading to a shortage of sand sediment on the coast closest to the delta and to the dominant erosion of the coastline. The nearshore enrichment of mud particles carried by waves and tide current contaminates strongly the coastal ecosystem.

The vulnerability of the coastal areas to the sea level rise will be better addressed due to the new integrated approach of the sediment yields. The link with the experience of the Tunisian and French observatories will help the countries to develop Mediterranean environmental monitoring on the long term, which is crucial to provide answers to a large array of environmental questions, in relation with socio-economic and governance issues. The focused goal of the RYSCMED outcome is addressed to the implantation of Nature Based Solution to enhance urbanized Tunisian coast resilience.

\section{References}

1. WCRP: The World Climate Research Programme Accomplishment Report (2013).

2. AFED: Arab Environment: Sustainable Development In A Changing Arab Climate. Annual Report of Arab Forum for Environment and Development, Saab, N. and Sadik, A. (Eds.), Beirut, Lebanon. Technical Publications (2016).

3. I.H.E.E.: Ingénierie de l'Hydraulique, de l'Equipement et de l'Environnement, 2007. Etude de la vulnérabilité environnementale et socio-économiques du littorale tunisien face à une élévation accélérée du niveau de la mer due aux changements climatiques et identification d'une stratégie d'adaptation. Ministère de l'Environnement et du Développement Durable. Rapport définitif, Phase I (2007).

4. El Raey, M.: Impact of Sea Level Rise on the Arab Region (2012).

5. Esonni, N.: Etude de la dynamique des sels nutritifs et des métaux lourds en relation avec relation avec la sédimentologie et l'hydrodynamique dans le large du Golfe de Tunis. Thèse de Doct., Univ. Tunis II, Fac. Sci. de Tunis, p 229 + annexes (1998).

6. Kotti, F., Dezileau, L.,Mahé, G., Habaieb, H., Bentkaya,M., Dieulin, C., Amrouni, O. : Etude de l'impact des barrages sur la réduction des transports sédimentaires jusqu'à la mer par approche paléohydrologique dans la basse vallée de la Medjerda. Proc. IAHS, 377, 6776 (2018).

7. Hzami, A., Amrouni, O., Romanescu, G., Stoleriu, C.C., Mihu-Pintilie, A., Abdeljaouad, S.: Satellite images survey for the identification of the coastal sedimentary system changes and associated vulnerability along the western bay of the Gulf of Tunis (northern Africa). Proc. IAHS, 377, 83-89 (2018).

8. Delile, H., Abichou A., Gadhoum A., Goiran J-Ph., Pleuger E., Montchambert J-Y., Wilson A., Fentress E., Quinn J., Ben Jerbania I. and Ghozzi F.,: The Geoarchaeology of Utica, 
Tunisia: The Paleogeography of the Mejerda Delta and Hypotheses Concerning the Location of the Ancient Harbor, Geoarhcaeology : An International Journal 30, 291-306 (2015).

9. Benmoussa, T., Amrouni, O., Dezileau, L., Mahé, G., Abdeljaouad, S. : The sedimentological changes caused by human impact at the artificial channel of Medjerda-River (Coastal zone of Medjerda, Tunisia). Proc. IAHS, 377, 77-81 (2018).

10. Helali, M.A., Added, A., Zaaboub, N., Oueslati, W.: Géochime des métaux lourds dans les sediments marins de surface du delta de l'Oued Medjerda. RME 3: 487 -498 (2009). 